\title{
Kantian Theory, Nuclear Weapons, and Coercive Anti-Proliferation
}

\author{
Antonio Franceschet
}

This article examines the issue of coercively preventing states from acquiring and possessing nuclear weapons. In questioning whether such coercion is morally legitimate, I argue that Immanuel Kant's (1724-1804) political theory contains important resources compared with three rival perspectives: Realpolitik, the Just War Tradition, and Deontological Pacifism. I also argue that coercive anti-proliferation measures are conditionally legitimated by three distinctive Kantian concepts: First, his concept of International Justice allows for coercion against genuinely aggressive states engaged in nuclear aspiration. Second, given the imperfections of international justice institutions, his concept of a State of Peoples-an authorized global governance body-seems to provide a better guarantee of just forms of coercive nuclear anti-proliferation. Third, supplementing the first two concepts, Kant discusses a Cosmopolitan Right to share the earth's surface. This concept justifies coercive anti-proliferation when a people's right to existence as citizens of the earth is threatened by nuclear weapons.

Keywords Kant, nuclear weapons, proliferation, coercion, justice, cosmopolitanism

\section{Introduction}

Since their development and use 68 years ago, nuclear weapons have posed a fundamental challenge in world politics. The Cold War conflict between the United States and the Soviet Union was made more dangerous, yet also, some think, more stable as a result of these weapons. ${ }^{1}$ Other powers including Great Britain, France, and China sought quickly to join the so-called nuclear club. Subsequently, preventing the spread of nuclear weapons beyond that club has been the core interest of the nuclear non-proliferation regime. Yet preventing states like Israel, India, Pakistan, and North Korea from acquiring them has proved impossible, despite the centerpiece of that regime, the Nuclear NonProliferation Treaty (NPT). Although this regime is based primarily on diplomatic and persuasive forms of preventive action, coercive measures have 
recently become more salient (Meier and Daase 2013). Labels like counterproliferation and anti-proliferation have been coined to describe such measures.

The use of military force to prevent a state from acquiring nuclear weapons has a long and controversial history. As far back as World War II, in specific campaigns in the general war effort, the Allied states thwarted Nazi Germany's nuclear program (Malin 2013, 90-1). After the war, with the exception of legitimate self-defence, the United Nations (UN) Charter outlawed military force against the territorial integrity and political independence of any state unless authorized by the Security Council. The preventive use of force is generally viewed as illegal (Armstrong, Farrell and Lambert 2012, 135). Thus, Israel's preventive strike in 1981 against Iraq's Osirak nuclear program was condemned in the UN General Assembly and Security Council. Similarly, the U.S.-led coalition against Iraq in 2003 to eliminate an alleged weapons of mass destruction program was condemned by most of the international community as illegal, unnecessary, and dangerous; yet by joining the coalition, at least some states endorsed the need for preventive action (Tesón 2005).

Focusing on the Enlightenment philosopher Immanuel Kant's (1724-1804) political theory, this article analyzes the moral legitimacy of using coercion to prevent states from acquiring nuclear weapons. Although Kant lived in a prenuclear world, the generality of his theory provides important resources for analyzing the profound challenges such weapons pose to a just world order. Compared with three alternative perspectives on international justiceRealpolitik, the Just War Tradition, and Deontological Pacifism-Kantian theory supports a multidimensional, principled perspective on the ethics of coercion in world politics. While opposed to the use of unauthorized and unjust international coercion, his theory grounds anti-proliferation measures by virtue of three concepts:

- International Justice, which permits coercion to vindicate inter-state rights to freedom from aggression;

- The State of Peoples, the existence of a legitimate and competent world political and juridical authority to use coercion against threats to a wider community of states and individuals;

- Cosmopolitan Right, a guarantee that, as citizens of the earth, people have freedom not just from inter-state aggression or from the problems of incomplete justice mechanisms, but to a share of the earth's surface.

These three Kantian concepts are relevant to current debates on nuclear weapons. Given the weaknesses of the global non-proliferation regime, and the possibility of new, threatening aspirants, it is likely that states will seek more robust antiproliferation measures. How such measures are justified will matter greatly for their overall legitimacy. My application of Kantian theory suggests that traditional rationales for coercively hindering nuclear aspirants are insufficient 
because they are based on a clear-cut distinction between nuclear aggressors and innocent would-be victims. While such a distinction is central to conventional understandings of international justice, it is ultimately inadequate because of the questionable authoritative competence to apply military force justly in a decentralized world order. Moreover, traditional rationales are limited because they ignore the danger that nuclear weapons pose, not just for sovereign states, but for people as global citizens. Thus, Kantian theory provides a critical resource for assessing the limits of preventive force within the current non-proliferation regime.

This article has two main sections. In the first, I outline the relevant differences among three perspectives on the political morality of war, peace, and nuclear weapons: Realpolitik, the Just War Tradition, and Deontological Pacifism. Although Kant is often placed in the Deontological category, in the second section I demonstrate how this is too narrow a reading of his political theory, particularly as regards the more specific problem of preventing the immoral acquisition and use of nuclear weapons. Section two also outlines how the three Kantian concepts discussed above apply to the problem of justifying the use of coercion as a tool of nuclear anti-proliferation.

\section{Three Perspectives on Ethics, War, and Nuclear Weapons}

Kant's political theory incorporates, but supersedes, the core insights of three salient perspectives on the ethics of war, peace, and nuclear weapons: Realpolitik, the Just War Tradition, and Deontological Pacifism. This section establishes the relative uniqueness of Kant's vision of international justice as a basis for unpacking the relevance of his key concepts to the problem of justifying coercive nuclear anti-proliferation.

\section{Realpolitik}

Kenneth N. Waltz is an important contemporary exponent of Realpolitik. His famous argument that the spread of more nuclear weapons "may be better" than the pursuit of non-proliferation is hotly disputed (Sagan and Waltz 2013). ${ }^{2}$ For Waltz, policy on nuclear weapons should not be based on moralistic or knee-jerk fears of their potential use but on the "military logic of self-help systems" (Sagan and Waltz 2013, 4). In a condition of anarchy, states must provide the means for their own survival and self-protection. Although Waltz avoids an explicit discussion of ethics, he clearly adheres to the basic assumptions of Realpolitik: State leaders have no obligations per se to other states and, therefore, they have a morally unconstrained liberty to take any actions necessary to guarantee national self-protection vis-à-vis others (see Forde 1993).

Waltz concedes that under certain circumstances the spread of nuclear 
weapons would warrant anti-proliferation policies. If nuclear aspirants were to use the weapon to make a "blackmailer's threat more effective, then nuclear weapons are bad for the world" (Sagan and Waltz 2013, 5). Yet he asserts this is theoretically possible but unlikely in the real world. Historically, rather than blackmail, states have used nuclear weapons only for "defence and deterrence, [policies that] are made easier and more reliable by the spread of nuclear weapons." Moreover, we should judge nuclear weapons not by abstract ethical categories of rightness but by whether the "use of force is more or less likely and in ways that promise to be more or less destructive" (Sagan and Waltz 2013, 5). Thus, Waltz's version of Realpolitik holds that nuclear weapons have been a positive force because they reduced the utility of war in the post-World War II era:

Remarkably, general war was avoided in a period of rapid and far-reaching change: decolonization; the rapid economic growth of some states; the formation and tightening of blocks; and the eventual dissolution of one of them; the development of new technologies; and the emergence of new strategies for fighting guerrilla wars and deterring nuclear ones (Sagan and Waltz 2013,4).

He concludes that even if systemic global counter-proliferation were possible, we would lose a weapon that allows the anarchic system to "absorb changes and contain conflicts and hostilities" (Sagan and Waltz 2013, 4). For Waltz, today's counter-proliferation practices, led by the United States, rest on dubious Eurocentric assumptions about which states can be trusted to rationally utilize a nuclear capability (Sagan and Waltz 2013, 3, 14).

\section{The Just War Tradition}

For the Just War Tradition, I take Michael Walzer to be the most interesting contemporary representative. In general, Walzer follows the presumption in this tradition that moral judgements about right and wrong are possible even in the proverbial state of nature. However, he gives this tradition a modern, liberal orientation by arguing that state rights to freedom from aggression are based on the human rights of their individual human members (Walzer 1977, 53). When a political community is forced by another state to fight, it is the people that are victims of aggression and who must resort to a just war (Walzer 1977, 51-2).

This is a fairly conventional and widely accepted morality, but is it plausible in a nuclear world? Strikingly, Walzer writes that "[n] uclear weapons explode the theory of just war. They are the first of mankind's technological innovations that are simply not encompassable within the familiar moral world" (Walzer 1977, 282). War's ostensible political utility as a tool for aggression/resistance to aggression may no longer hold intact with such weapons. The scale of death and destruction from nuclear weapons seems impossible to justify. "And yet," 
he reflects, "there are other notions, also familiar, having to do with aggression and the right of self-defence, that seem to require exactly that threat [of using them]" (Walzer 1977, 282). Here Walzer searches for something practical in the underlying foundations of the Just War Tradition to support a conditional permission for nuclear deterrence. With some ambivalence, he concludes that the Cold War situation of "mutually assured destruction" leaves leaders little opportunity for moral purity. To use the weapons in war is immoral and admits no exception. But to engage in a "kind of bluff" (Walzer 1977, 271) in which one prepares and threatens "to kill, is not same as killing." Yet it is "frighteningly close-else it would not work" (270).

Nuclear deterrence in the Cold War meant leaders and their societies engaged in a form of "criminality," in Walzer's assessment (Walzer 1977, 283). ${ }^{3}$ Yet such criminality can be excused under the label "supreme emergency" (Walzer 1977, 251-59; 2005, 33-50). These situations do not eviscerate a human capacity and duty for moral choice. Rather, such duties are suspended because of the risks involved in being strictly moral under dangerous circumstances. How is this ultimately different from Realpolitik? Walzer rejects the notion that states qua states simply respond amorally to external stimuli by doing whatever things are needed to survive. Instead, he claims that just states respond to a dangerous world by refraining from aggression and by resisting-as far as possible-doing evil things in the process of resisting others' aggression. For Walzer, when the Cold War ended, a nuclear supreme emergency also ended because the Soviet Union ceased to exist, thus removing any justification for the United States' "unwilling criminality": "We [in the U.S.] accepted the risk of nuclear war in order to avoid the risk, not of ordinary, but of totalitarian subjugation" (Walzer 2005, 48-9).

The end of that risk today means that just, liberal states, like the United States, no longer have moral permission to resort to the moral criminality of deterrence $v i s-\grave{a}$-vis less threatening, but, by all means, potentially dangerous nuclear aspirants. Here Walzer employs the Just War Tradition free from the shadows of a "supreme emergency" to argue that the United States and other just states may use coercion for counter-proliferation against unjust states. If needed, such coercion may be unilateral or preventive, depending on the circumstances. He suggests that although Israel needed military force in 1981 against Iraq's nuclear program, the United States could have used coercive inspections and containment measures "short of war" against Saddam Hussein's regime in 2003 (Walzer 2005, 148). Despite disagreeing with the Bush administration's policy of regime change in Iraq, Walzer believes unjust nuclear aspirants generally need to be coerced and controlled. In a statement that applies to Waltz as much as it does to the political Left, Walzer complains of "a constant temptation of antiwar politics: to pretend there really isn't a serious enemy out there.... This pretence certainly keeps things simple, but it is wrong in every possible way." It is "insane" he claims, to believe that conventional deterrence can prevent unjust leaders in 
many of today's would-be nuclear states from using the weapons as a means of blackmail or even of war (Walzer 2005, 152-53).

\section{Deontological Pacifism}

This perspective is a principled critique of both Realpolitik and the Just War Tradition. Putting the words Deontology and Pacifism together in a single perspective requires a brief explanation. Unlike with Realpolitik and certain core tenets of the Just War Tradition, a Deontological approach holds that "actions should be judged by their inherent rightness and validity not by the goodness or badness of policy outcomes" (Amstutz 2013, 74). Where Waltz views the acceptability of nuclear weapons, deterrence, and proliferation from the standpoint of whether they produce stability, and Walzer struggles to find a conditional permission for the weapons for deterrence in a "supreme emergency," a deontologist would take a completely different view: It is never permissible to use an immoral means to achieve an end, even one that is morally good. "Pacifism" is normally based on a Deontological premise: War is wrong because it involves killing and human suffering (Lackey 1989, 6). Taken together, a Deontological Pacifist perspective argues that war is never a morally valid instrument for collective self-protection and resisting aggression. It follows for many adherents of this perspective that possessing nuclear weapons is impermissible precisely because they threaten mass killing (Lackey 1989, 131).

In many key respects, Kant is an obvious illustrative exponent of Deontological Pacifism. His categorical imperative is a textbook example of deontological ethics (Stewart 2009, 35; but see Wood 2008). Two key formulations of the imperative are relevant to this discussion of war and nuclear weapons:

- The Formula of Universal Law: "Act as if the maxim of your action were to become through your will a universal law of nature" (italics in original, Kant 1964, 89).

- The Formula of the End in Itself: "Act in such a way that you always treat humanity, whether in your own person or in the person of any other, never simply as a means, but always at the same time as an end" (Kant 1964, 96).

At a very general level, the use of violence to resolve conflicts fails these two formulations of the moral law. War cannot be universalized without contradiction as a just means of rights-vindication; and wars tend to degrade humans as instruments of killing and targets of destruction. The impact of the categorical imperative on Kant's approach to international politics is clear: "Now moralpractical reason in us pronounces its irresistible veto: There shall be no war, neither between me and you in the state of nature, nor between us as states... this is not the manner in which everyone ought to seek his right" (Kant 2006a, 148). His advocacy of a "perpetual peace" league among states and for national disarmament are ultimately borne by the deontological logic of the categorical 
imperative (Kant 2006b).

During the 1980s, Deontological Pacifists drew from the categorical imperative to support "an unequivocal opposition to nuclear proliferation and a corresponding requirement that all states undertake unilateral and global nuclear disarmament without condition" (Doyle 2010, 91). Yet there are two vexing problems with this opposition and such requirements: First, how are states to credibly ensure their survival and self-protection?; and second, with respect to nuclear weapons, how are states to implement the demands of ethics when others are unwilling (or, in their view, "unable") to disarm? Kant is far more nuanced a political thinker than some of his interpreters have made it seem (see Doyle 2010).

To summarize, I argue that Kant's political theory is multi-faceted because it absorbs key aspects of all three traditions discussed above, Realpolitik, Just War, and Deontological Pacifism. Yet he orders the central elements of each in a way that limits their weaknesses. First, like Waltz, Kant accepts that the anarchic structure of world politics leaves states in a situation of self-help, independent to pursue self-protection as they see fit (Kant 2006b, 79-80; 2006a, 111). Yet, second, like Walzer, Kant accepts that, even in a state of anarchy, some actions constitute unjust aggression and states have an individual and collective right to coercively resist (2006a, 140; see also Orend 2000; compare with Willisams 2012). Thus, Kant rejects pacifism as a short term response to injustice. Third, however, like Deontological Pacifism, Kant rejects the amoralism of Realpolitik and the expediency that too often creeps into the Just War Tradition, exemplified by Walzer's "supreme emergency" category. National or collective self-protection may only occur through principled or universally permitted actions that respect the humanity of the species, as discussed in the next section. Finally, any coercive means used by states to ensure self-protection, individually or collectively, must not prevent the eventual realization of lasting peace and justice. Kant's political theory thus combines an appreciation of the demands and dilemmas of selfhelp in anarchy, of the inherent justness of countering aggression, and of the imperative for pursuing moral means to achieving peace. The next section advances and applies the multi-dimensionality of Kant's political theory to the more specific issue of the legitimacy of using coercion to prevent nuclear acquisition.

\section{Kantian Political Theory and Coercive Anti-Proliferation}

When do states or international institutions have the moral authority to coercively prevent a state from achieving nuclear weapons capability? I argue that there are three concepts in Kantian political theory that lend support to coercive anti-proliferation under certain circumstances. These concepts are derived 
from his principal texts on political theory, especially but not exclusively The Metaphysics of Morals (Kant 2006a) and "Perpetual Peace" (Kant 2006b). First, the concept of International Justice allows coercion based on a right of states to self-protection from aggression. The second and third Kantian concepts are more radical and original and require an elaboration of how they apply to nuclear issues; they suggest that coercive authority is not reducible to situations of interstate aggression presumed by the concept of International Justice. Thus, the State of Peoples and Cosmopolitan Right give distinctive bases for rethinking current international practices and institutions for coercing nuclear aspirants.

\section{International Justice: Preventing Aggression}

Coercive anti-proliferation generally finds support in Kant's concept of International Justice, the right of states to self-defence. Yet there are two sides to the coin of International Justice: acting to prevent aggression may also entail recognizing a permission of states to acquire nuclear weapons for defensive reasons.

With respect to the first side of the coin, Thomas Doyle $(2010,104)$ argues that Kant's theory allows states to acquire a nuclear deterrent capability because of a moral right to self-defence. Neither the existing Nuclear Non-Proliferation Treaty (NPT) regime nor the possibility of instability due to arms racing can override such a basic right (Doyle 2010, 107). If Kantian theory accepts this right, then it would be difficult to locate in his texts a blanket right of states or the UN to coercively prevent nuclear acquisition. Yet the other side of the coin of International Justice logically entails the right of states to coercively thwart the aspirant state's designs. Thus, the International Justice rationale for counter-proliferation encounters the problem of the security dilemma and the contradictions and indeterminacy that results. Applied in an anarchic context, International Justice both permits and disallows nuclear acquisitions. This is so even where cooperative organizations like the UN exist or where legal regimes like the NPT are in effect.

There is no easy way out of this indeterminacy built within the International Justice rationale for coercion. But the stakes are extraordinarily high given the nature of the weapons. States that continue to feel threatened will seek to acquire weapons; and others will, on the same basis, seek to prevent the aspirants. Kantian theory explains that each has a provisional or conditional title to acquire/ coerce. Managing this problem is not simply a prudential issue but a moral task. A moral politician, according to Kant, seeks to reform existing international laws, practices, and policies to dismantle what on the surface seem like intractable dilemmas (Kant 2006b, 101-04). The NPT, the current system of vindicating rights in relation to the distribution of the entitlement to possess weapons, clearly needs reform. Moreover, the Security Council as the mechanism for preventing aggressive nuclear acquisition needs reform. The conceptual limits 
of International Justice as a justification for coercive anti-proliferation suggest a need to go beyond a focus on inter-state aggression as the core moral issue at stake with nuclear weapons. For this reason, there is value in considering the two other concepts within Kant's political theory that, in principle, support coercive anti-proliferation.

\section{Enforcement by a State of Peoples}

Kant's solution to the international state of nature is a perpetual peace federation (Kant 2006b). Such a federation can be viewed as a developed, mature version of international anarchy; it is an association capable of reducing the indeterminacy of rights claims. But it has no coercive authority over states. Kant suggests this federation is indispensible yet imperfect compared to a better concept, a State of Peoples:

As concerns the relations among states, according to reason there can be no other way for them to emerge from the lawless condition, which contains only war, than for them to relinquish, just as do individual human beings, their wild (lawless) freedom, to accustom themselves to public binding laws, and thereby to form a state of peoples (civitas gentium), which, continually expanding, would ultimately comprise all the peoples of the world (Kant 2006b, 81).

Kant recognizes that states do not "want the positive idea of a world republic at all (thus rejecting in hypothesi [practice] what is right in thesi [theory]), [and therefore we must endorse]... only the negative surrogate of a lasting and continually expanding federation that prevents war [and] can curb the inclination to hostility and defiance of the law, though there is the constant threat of its breaking loose again" (Kant 2006b, 81).

Typically, the State of Peoples concept is overlooked in Kant's political theory. Yet scholars like Pauline Kleingeld (2004; 2012, 49-58) and Georg Cavallar (1999, 122-31) have elevated its importance. They suggest that Kant's apparent rejection of the concept is conditional rather than total. It is clear Kant resisted the idea that a State of Peoples could be imposed on states coercively; for moral reasons, states must develop a shared idea of justice and then be willing to impose it on themselves. In other words, the State of Peoples is something states may gradually accept over time once they learn to trust each other and have undergone supportive domestic constitutional changes that dovetail with a peaceful international order. My objective here is not to argue that we need to wait for perfect conditions or until a State of Peoples forms to authorize the coercive prevention of nuclear acquisitions. Rather, the point is that the State of Peoples concept usefully reveals limits in current practices in the global nonproliferation regime. ${ }^{4}$

Theoretically, if states grow more accustomed to the idea of submitting 
themselves to public binding laws, and form a State of Peoples, what difference would it make? Juridically, coercion would be a matter of living under commonly accepted laws rather than under alien powers or of simply using force as an instrument of self-protection (see Kant 2006b, 78). If a State of Peoples emerges, then coercion in relation to nuclear acquisition would be qualitatively different than it is with International Justice. One could only conceive of states growing accustomed to submitting to a common external, coercive constraint after (or at least simultaneous with) global nuclear disarmament. If, as Kant suggests, a negative surrogate of a peace federation depends on the promise of eventual disarmament, it would apply a forteriori to states that have grown accustomed to submitting to external laws. ${ }^{5}$ After that point, a state's policy to acquire nuclear weapons would pose a "constitutional" challenge to the State of Peoples, analogous perhaps to a rebellion from the shared vision of international justice that underpinned its legitimate establishment. Sudden acquisition and/or possession would be automatically injurious to the rights of all others, and would be subject to coercive prevention as a matter of law enforcement. Self-defence claims by such a state would not be a legitimate excuse to acquire the weapons.

In a State of Peoples context, we can imagine that the possession of nuclear technologies would be coercively controlled. But coercion need not involve the use of military force as the first or final basis for guaranteeing the law. For Kant, coercion is principally about an external hindrance on freedom consistent with the freedom of all (Kant 2006a; see also Ripstein 2009); it is not dependent solely on the threat or use of physical force. Ideally, lawful coercion can be achieved without recourse to violence. Similar to Walzer's comment that "moral talk is coercive" (1977, 12), Kant suggests that the transcendental principle of publicity has a coercive effect (Kant 2006b, 106). A State of Peoples would therefore also presuppose that all uses of nuclear technologies are civilian and, therefore, publically observable and monitored.

The current institutional order may be described as being based on a mixture of conventional concepts of International Justice and a non-proliferation control regime. The former distinguishes between aggression and peace rather than among categories of weapons. The latter is premised on the notion that nuclear weapons pose a special concern compared to conventional weapons, and they require an exceptional set of (albeit, in the first instance voluntary) control arrangements. The UN Charter and the Security Council's specific responsibility to maintain international peace and security are premised on a substantial acceptance of the basic theory of aggression within the International Justice concept. The 1968 NPT, the centerpiece of the non-proliferation regime, is premised, formally at least, on the notion that civilian use of nuclear technology ought to be the only kind permissible for states (much like the Baruch Plan). As is well known, the NPT's legitimacy is constantly challenged by the fact that the states legally permitted to possess nuclear weapons have not yet acted on the 
obligation to disarm, and show no signs of moving in that direction. Moreover, the non-proliferation regime has been interpreted recently by some states in the UN-particularly Western states-as requiring more coercive policing and controlling of certain non-nuclear states under the NPT such as Iran (Meier and Daase 2013).

Compared with a State of Peoples, the problems of the current institutional order stand out. The continued reliance on an unreconstructed theory of aggression within a decentralized, anarchic order permits states to defend themselves. The NPT allows only some states to use nuclear weapons as a means to deter attack. Allowing nuclear entitlements to some and not others and then using the notion of law enforcement to coercively prevent nuclear acquisitions is an unjust order. This is because it combines an acceptance of self-help and self-protection for some states and the threat of external coercive control over others. As Doyle (2009) argues, such an international order is unjust and could be rightfully resisted as unfair. While many defend the non-proliferation regime as better than complete nuclear anarchy (or "anything goes"), an arguably better and morally relevant baseline is found in the Kantian concept of the State of Peoples.

\section{Enforcing a Cosmopolitan Right to Share the Earth}

For Kant, Cosmopolitan Right is not merely an afterthought to domestic and international politics; it is a "necessary supplement" to these other domains (2006b, 85). His discussion of this right focuses heavily on the notion of hospitality, that is, rules that govern a host in relation to guests. People have an inherent right to travel and make contact with other peoples, and to not be received with hostility or in ways that endanger their lives. Hosts have a right to limit or contain such contacts to preserve their distinct homeland. But his discussion of hospitality is enlarged as it becomes clear that Cosmopolitan Right is a branch of a more general metaphysics of morals. Trading relations are governed under this principle as are prohibitions on imperialism and colonialism, whereby the visitors overwhelm and dispossess the "homeowners."

There is an underlying unity to these issues raised under Cosmopolitan Right: Persons have "the right of common possession of the surface of the earth" (Kant 2006b, 82). They have a right to settle and live on some part without denying others the same. Jeremy Waldron (2000) argues that Kant's cosmopolitan theory is principally about the ethics of living side-by-side within the earth's bounded spatial limits. Following Waldron's interpretation, I raise here the implications of cosmopolitan right for coercing a state's acquisition of nuclear weapons.

Nuclear weapons raise exactly the issues that are central to Kant's concept of Cosmopolitan Right. In some ways, they are like any other issues that affectnegatively or positively-the rights of people to share the earth's surface, such as migration, trade, war, and imperialism. In others, however, nuclear weapons raise 
unique and special considerations.

Historically, Kant argues that human beings and societies are driven by a dialectic of "unsocial sociability" (2006c, 4). We are curious about others and want to interact with them. But this curiosity is limited. At the very same time, we seek to force our own conception of justice on others and fear people that may pose a challenge to our values. The entire surface of the earth, even the seemingly most uninhabitable parcels, became populated-as someone's "home," through human practices like war (driving people apart) and trade (supplying people with goods unavailable at "home"). But once the entire surface has been populated, and there is no real possibility that war and disagreement can push humans to hitherto uninhabited corners, we must finally accept the need to live together side-by-side. This has implications both for how subsequently acknowledged claims to homelands are treated, and also for any actions that affect the very basic right to survive and coexist on the planet.

In principle, weaponized nuclear technology is just like any other tool invented by humans within the dialectic of unsocial sociability. If nuclear weapons can be used within the political bounds of warfare, as a way to drive away threats of invasion, they are no different than conventional weapons. Yet neither war nor nuclear weapons are containable within ethical boundaries. Kant believes that political violence degenerates into a "a war of extermination" (2006b, 71), thus challenging Cosmopolitan Right. Obviously, the use of nuclear weapons for deterrence potentially slides into exactly this.

In practice, then, the acquisition of nuclear weapons has unique and special implications for Cosmopolitan Right. Like genocide, the use of nuclear weapons resolves the problem of living-side-by side in a way that threatens the right of peoples to exist as such. When a state leader like Iran's former president Mahmoud Ahmadinejad speaks of wiping Israel from the map, he seems to be threatening exactly the right to share the earth. ${ }^{6}$ The same might be said of North Korean leader Kim Jong-un's reported rhetoric about his preparedness to "annihilate the enemy." Acquisition of nuclear weapons with this intent is especially alarming - and violates not just the particular rights of Israelis (or South Koreans and Americans), but the principle of Cosmopolitan Right. As Kant writes, "The growing prevalence of a (narrower or wider) community among the peoples of the earth has now reached a point at which the violation of right at any one place on the earth is felt in all places" (2006b, 84).

This raises the question of whether there is an authority to coerce a state's acquisition of nuclear weapons on distinctly cosmopolitan grounds. I suggest that Kant's political theory supports a coercive entitlement here that is conceptually distinguishable from the two others discussed above related to International Justice and the State of Peoples. This entitlement has exactly the same foundation as coercing acts of genocide. Permission to coerce on this basis falls on any actor that can do something to right the wrong. Allan Buchanan and Robert Keohane's 
(2004) proposal for a cosmopolitan institutional framework to prevent acquisition of weapons of mass destruction conceivably fits within this justification.

It is also worth mentioning that nuclear weapons raise the possibility not just of genocide but omnicide: destruction of the human species or of the earth's capacity to sustain human life. Although this prospect was more salient during the Cold War, the theoretical possibility remains. Kant could not conceive this. Yet as Peter Fenves (2003) observes, Kant seems to accept that even if, in the vast scope of human relations, huge numbers of the species perish through violence, all that is necessary for human progress-and the eventual triumph of an ethical commonwealth-is the survival over time of at least some peoples (see Kant 2006b, 103). Obviously, global nuclear holocaust threatens even these people, those who would inherit the earth after the centuries of war endured by the progenitors. If coercion to uphold a right to share the earth is valid, it would be $a$ forteriori valid to a threat to the species as such.

At least two objections are possible against the notion of using Kant's concept of Cosmopolitan Right to ground coercion of a state's nuclear acquisition policy. The first is that Kant's texts are quite restricted and focused on specific issues closely related to hospitality rather than violence and war. The second is that Kant does not seem to allow for coercion to guarantee or vindicate Cosmopolitan Rights.

These objections are not very convincing. As noted above, Kant's apparent restriction of cosmopolitan right to issues of hospitality does not prevent application of the underlying principle to other issues. Particularly because he mentions trade and the moral wrong of imperialism and colonialism in relation to the same right, it should follow that sharing the earth's surface, rather than hospitality, is his underlying concern (Kant 2006b, 82-4). Moreover, he says that cosmopolitan right is exactly like domestic and international right, i.e., it is something "ultimately regulated by public laws" (Kant 2006b, 82). And all right involves the authorization to coerce. Like International Justice, there may not be a common external constraint to guarantee consistent domains of the earth's surface (as in domestic politics), but this does not nullify the rights in question.

I am not suggesting that Cosmopolitan Right by itself is a sufficient basis for reforming today's institutions and practices governing nuclear weapons. Nor am I suggesting that a centralized or external coercive body be employed for cosmopolitan reasons. Simply, Cosmopolitan Right provides a non-redundant moral principle: Acquisition and use of nuclear technologies must be consistent with the principle that all people have a right to share the surface of the earth, and have the obligation to live together side-by-side in spite of their differences and fears of each other.

Cosmopolitan Right, then, is a distinctive supplementary concept to International Justice and the State of Peoples. It allows an alternative basis for assessing the ethicality of today's nuclear non-proliferation regime. International 
legal rules should not hinder-to the contrary, they should promotetechnologies that would allow the world's citizens (living in ever more dense conditions) to live side-by-side peacefully. The NPT's permission for states to develop peaceful nuclear technologies, and promotion of an obligation for the peaceful sharing and transfer of the same, is consistent with this Kantian principle. But any use of coercion to hinder the development of civilian nuclear technologies in a way that prevents a people from continued use of a "home" on earth, or from sharing the earth's surface, would be unjust. Equally, as discussed above, use of this technology with an intent to annihilate or deny a people a share of the earth is something that affects everyone, and is coercible. In this way, Kantian cosmopolitanism goes beyond a conventional theory of aggression, and is not reducible to self-protection for sovereign states.

\section{Conclusion}

Since their invention, nuclear weapons have posed a challenge to conventional theories and practices of war and international politics. During the Cold War, the main issue was managing the East-West deterrent and, to a lesser degree, proliferation. In the past two decades, preventing proliferation to so-called rogue states and even terrorist non-state actors has been a more salient concern. At the same time, the UN Security Council has asserted itself in the area of coercively preventing and controlling states' acquisition and possession of nuclear technologies: Iraq, Iran, Libya, and North Korea have all been targets of sanctions. Iraq was invaded and subjected to regime change, albeit by a coalition of states that lacked uncontested Security Council authorization.

This article has examined the ethics of coercively limiting the possession of nuclear weapons by sovereign states. I have argued that Kant's political theory contains important resources because it incorporates and surpasses the strengths of rival ethical approaches to nuclear weapons such as Realpolitik, the Just War Tradition, and Deontological Pacifism. Kant's theory contains a strong presumption against the use of force. However, I have also shown how coercive anti-proliferation measures are morally legitimated by three concepts within Kantian theory. First, International Justice necessarily allows for coercion against genuinely aggressive states engaged in nuclear aspiration. Second, Kant shows the need for a State of Peoples to guarantee a just form of anti-proliferation. Third, he advocates a Cosmopolitan Right justification for sharing the earth's surface, one that provides a distinctive and timely rationale for anti-proliferation policies in an era of globalization.

The current institutional order and anti-proliferation practices are flawed because of ineffectiveness in justly hindering potentially aggressive nuclear acquisitions and in achieving general and systemic disarmament. Reforming the 
current system requires thinking based on general principles of justice rather than fear of certain categories of states as such, or of historical enemies as such. Although Thomas Doyle (2010) is correct in using Kantian theory to show that nuclear acquisitions are not inherently unjust, I have argued that International Justice assumptions are insufficient for considering the ethicality of permitting and coercively preventing the spread of nuclear technologies. Thus, the State of Peoples and Cosmopolitan Right are important dimensions of Kantian theory with considerable utility for contemporary ethical and policy debates. Unlike Realpolitik, Kantian theory does not ignore ethical obligations among peoples. Unlike the Just War theory, Kantian categories do not simply "explode" in relation to nuclear technologies (to use Walzer's description). This is not merely because Kant's thought is, as is often remarked, so systematic and general, that particular political facts and worldly developments are not relevant (Flikschuh 2010, 6). To the contrary, it is because Kant extended and applied his account of justice to the actual conditions of states as they are, and people as they are, living together sideby-side in immensely dangerous and risky conditions.

\section{Notes}

1. Compare the view of former United States Secretary of Defense Robert S. McNamara: "In the end, we lucked out—it was luck that prevented nuclear war [during the Cold War]," (see Morris 2003) with scholars emphasizing the role of nuclear weapons in creating a "long peace" (Gaddis 1986).

2. Although the citations are to Sagan and Waltz, this volume consists of a debate where Waltz's position is set out in his own chapters. Although I will cite both names, the focus in this article is on Waltz not Sagan.

3. Walzer means "criminality" in a moral, not legal positivist sense. I thank an anonymous reviewer for prompting this clarification.

4. I thank an anonymous reviewer for asking for clarification of this point.

5. The 1946 Baruch Plan presented to the UN Atomic Energy Commission is perhaps the only historic precedent that anticipates, at least in the realm of nuclear weapons, a State of Peoples. Proposed by the U.S. government, the plan was to inter alia eliminate atomic weapons of mass destruction and establish international controls over the technology. The Soviet Union rejected the plan.

6. The Guardian. 2005. "Israel Should Be Wiped Off Map, says Iran's President." October 27. http://www.guardian.co.uk/world/2005/oct/27/israel.iran (accessed September 30, 2013).

7. $\quad B B C$ News. 2013. "North Korea Ends Peace Pacts with South.” March 8. http://www. bbc.co.uk/news/world-asia-21709917 (accessed September 30, 2013). 


\section{References}

Amstutz, Mark R. 2013. International Ethics: Concepts, Theories, and Cases in Global Politics. 4th ed. Lanham: Rowman \& Littlefield Publishers.

Armstrong, David, Theo Farrell, and Hélène Lambert. 2012. International Law and International Relations. 2nd ed. Cambridge: Cambridge University Press.

Buchanan, Allen, and Robert O. Keohane. 2004. "The Preventive Use of Force: A Cosmopolitan Institutional Proposal." Ethics \& International Affairs 18 (1): 1-22.

Cavallar, Georg. 1999. Kant and the Theory and Practice of International Right. Cardiff: University of Wales Press.

Doyle, Thomas E. 2009. “The Moral Implications of the Subversion of the Nonproliferation Treaty Regime." Ethics \& Global Politics 2 (2): 131-53.

Doyle, Thomas E. 2010. "Kantian Nonideal Theory and Nuclear Proliferation." International Theory 2 (1): 87-112.

Fenves, Peter. 2003. Late Kant: Towards Another Law of the Earth. New York: Routledge.

Flikschuh, Katrin. 2010. "Kant's Sovereignty Dilemma: A Contemporary Analysis." Journal of Political Philosophy 18 (4): 469-93.

Forde, Stephen. 1993. “Classical Realism.” In Traditions of International Ethics, eds. Terry Nardin and David Mapel. Cambridge: Cambridge University Press, 62-84.

Gaddis, John Lewis. 1986. "The Long Peace: Elements of Stability in the Postwar International System." International Security 10 (4): 99-142.

Kant, Immanuel. 1964. Groundwork of the Metaphysic of Morals, trans. H. J. Paton. New York: Harper Torchbooks.

Kant, Immanuel. 2006a. "Metaphysics of Morals." In Toward Perpetual Peace and Other Writings on Politics, Peace, and History, ed. Pauline Kleingeld. New Haven: Yale University Press, 110-149.

Kant, Immanuel. 2006b. “Toward Perpetual Peace: a Philosophical Sketch.” In Toward Perpetual Peace and Other Writings on Politics, Peace, and History, ed. Pauline Kleingeld. New Haven: Yale University Press, 66-109.

Kant, Immanuel. 2006c. "Idea for a Univeral History from a Cosmopolitan Perspective." In Toward Perpetual Peace and Other Writings on Politics, Peace, and History, ed. Pauline Kleingeld. New Haven: Yale University Press, 3-16.

Kleingeld, Pauline. 2004. "Approaching Perpetual Peace: Kant's Defence of a League of States and His Ideal of World Federation." European Journal of Philosophy 12 (3): 30525.

Kleingeld, Pauline. 2012. Kant and Cosmopolitanism: The Philosophical Ideal of World Citizenship. Cambridge: Cambridge University Press.

Lackey, Douglas P. 1989. The Ethics of War and Peace. Englewood Cliffs, NJ: Prentice Hall.

Malin, Martin B. 2013. "The Effectiveness and Legitimacy of the Use of Force to Prevent Nuclear Proliferation." In Arms Control in the 21st Century: Between Coercion and Cooperation, eds. Christopher Daase and Oliver Meier. New York: Routledge, 81-121.

Meier, Oliver, and Christopher Daase. 2013. "Introduction." In Arms Control in the 21st Century: Between Coercion and Cooperation, eds. Oliver Meier and Christopher Daase. New York: Routledge, 3-11.

Morris, Errol. 2003. The Fog of War: Eleven Lessons from the Life of Robert S. McNamara. 
DVD. Culver City, CA: Sony Pictures Home Entertainment.

Orend, Brian. 2000. War and International Justice: A Kantian Perspective. Waterloo, Canada: Wilfrid Laurier University Press.

Ripstein, Arthur. 2009. Force and Freedom: Kant's Legal and Political Philosophy. 1st ed.

Cambridge, MA: Harvard University Press.

Sagan, Scott Douglas, and Kenneth N. Waltz. 2013. The Spread of Nuclear Weapons: An Enduring Debate. New York: W.W. Norton \& Co.

Stewart, Noel. 2009. Ethics: An Introduction to Moral Philosophy. Cambridge, UK and Malden, MA: Polity.

Tesón, Fernando R. 2005. “Ending Tyranny in Iraq." Ethics \& International Affairs 19 (2): 1-20.

Waldron, Jeremy. 2000. “What Is Cosmopolitan?” Journal of Political Philosophy 8 (2): 227 43.

Walzer, Michael. 1977. Just and Unjust Wars: A Moral Argument with Historical Illustrations. New York: Basic Books.

Walzer, Michael. 2005. Arguing About War. New Haven, CT: Yale University Press.

Williams, Howard. 2012. Kant and the End of War: A Critique of Just War Theory. New York: Palgrave Macmillan.

Wood, Allen W. 2008. Kantian Ethics. Cambridge: Cambridge University Press.

\footnotetext{
Antonio Franceschet is Associate Professor of Political Science at the University of Calgary in Canada and the Chair of the International Ethics Section of the International Studies Association. He publishes widely on international political theory, international law, and ethics. His works include Kant and Liberal Internationalism: Sovereignty, Justice, and Global Reform (New York: Palgrave Macmillan, 2002) and (as editor) The Ethics of Global Governance (Boulder, CO: Lynne Rienner Publishers Inc, 2009). His articles have appeared in Ethics \& International Affairs, Journal of International Political Theory, Journal of Global Ethics, Policy and Society, Global Governance, and Review of International Studies.
} 
